\title{
UPAYA MENINGKATKAN HASIL BELAJAR SISWA DENGAN MENGGUNAKAN MODEL PEMBELAJARAN KOOPERATIF TIPE STAD (STUDENT TEAMS ACHIEVEMENT DIVISION) MATA PELAJARAN MATEMATIKA DI KELAS V SDN 065014 NAMO GAJAH MEDAN TAHUN PEMBELAJARAN 2017/2018
}

\author{
OLEH: \\ DUWI HARIANI SEMBIRING \\ (PGSD FKIP UNIVERSITAS KATOLIK SANTO THOMAS SU)
}

Mathematics tends to be difficult to be accepted and understood by students, so it is causing the intresting of students about mathematics quite low. The low result of study's student is to be a base to research, where the purpose of this research is to see the improvement of result of study's students in mathematics. The type of this research is a classroom action research by using STAD type cooperative learning model (Student Teams Achievement Division). It consists of two cycles which are planning, implementation, observation, and reflection. This research was held at SDN 065014 Namo Gajah Medan. The subject of the study was the students of grade V of SDN 065014 Namo Gajah Medan, which were 25 students, while the object was using cooperative learning model of stad type (student teams achievement division) inMathematics. The data collection techniques used tests and observations. From the results of data obtained from the observation of learning implementation, teacher activity in cycle I obtained 75 percent and for student activity obtained 71 percent and average of the learning outcomes obtained in the first cycle is 69.5. In the second cycle of teacher activity increased become 78 percent and for student activity also increased become 76 percent whereas for the average student learning outcomes increased become 78.24.From the results of research can be concluded the implementation of learning was good and the result of students' learning increased after using the model of cooperative learning type STAD (Student Teams Achievement Division) on Mathematics subjects especially prime numbers to determine FPB and KPK in $5^{\text {th }}$ Grade of SDN 065014 Namo Gajah Medan.

Keywords: Learning outcomes, Classroom Action Research, Cooperative Learning Model Type STAD (Student Achievement Division)

\section{PENDAHULUAN}

Latar Belakang Masalah

Pendidikan adalah proses pengembangan daya nalar, keterampilan, dan moralitas sebagai pengembangan potensi yang dimiliki oleh setiap manusia. Pendidikan dikatakan bermutu apabila proses pendidikan berlangsung secara efektif, manusia memperoleh pengalaman yang bermakna bagi dirinya dan produk pendidikan merupakan individu-individu yang bermanfaat bagi masyarakat dan pembangunan bangsa, sehingga mutu pendidikan dapat diukur dari aspek mutu masukan, mutu proses, mutu keluaran, dan dampak mutu kelulusan. 
Menurut Susanto (2013: 4) "belajar adalah suatu aktivitas mental yang berlangsung dalam interaksi aktif antara seseorang dengan lingkungan, dan menghasilkan perubahan-perubahan dalam pengetahuan, pemahaman, keterampilan, dan nilai sikap yag bersifat relatif dan konstan".

Menurut Susanto (2013: 5) Hasil belajar siswa adalah kemampuan yang diperoleh anak setelah melalui kegiatan belajar, karena belajar itu sendiri merupakan suatu proses dari seseorang yang berusaha untuk memperoleh suatu bentuk perubahan perilaku yang relatif menetap. Dalam kegiatan pembelajaran atau kegiatan instruksional, biasanya guru menetapkan tujuan belajar. Anak yang berhasil dalam belajar adalah yang berhasil mencapai tujuan-tujuan pembelajaran atau tujuan instruksional. Untuk mengetahui apakah hasil belajar yang dicapai telah sesuai dengan tujuan yang dikehendaki dapat diketahui melalui evaluasi. Hasil belajar meliputi: pemahaman konsep (aspek kognitif), keterampilan proses (aspek psikomotor), dan sikap siswa (aspek afektif).

Menurut Susanto (2013: 187) Pembelajaran Matematika merupakan suatu proses belajar mengajar yang meungandung dua jenis kegiatan yang tidak terpisahkan yaitu belajar dan mengajar. Kedua aspek ini akan berkolaborasi secara terpadu menjadi suatu kegiatan pada saat terjadi interaksi antara siswa dengan guru, antara siswa dengan siswa, dan antara siswa dengan lingkungan di saat pembelajaran Matematika sedang berlangsung. Di dalam proses pembelajaran guru harus memiliki strategi atau upaya untuk menciptakan lingkugan sekolah yang baik agar siswa dapat belajar secara efektif dan efisien sehingga tujuan pembelajaran tercapai.

Namun kenyataanya masih banyak guru belum menggunakan strategi atau model yang digunakan saat proses pembelajaran berlangsung, sehingga banyak siswa yang mengangap bahwa pelajaran Matematika adalah pelajaran yang sulit dan membosakan karena di pelajaran Matematika hanya berisi angkaangka sehingga banyak hasil belajar siswa yang rendah dan kurang memuaskan.

Hasil belajar dapat diperoleh dari setiap evaluasi dalam bidang studi yang diajarkan di sekolah dan dengan hasil belajar yang telah diperoleh maka dapat kita lihat mata pelajaran yang telah lulus dari KKM (Kriteria Ketuntasan Minimal) dan yang belum melampaui atau mencapai KKM (Kriteria Ketuntasan Minimal) dan mata pelajaran yang sering menjadi masalah dari hasil belajar adalah pelajaran Matematika. Dari hasil observasi di SDN 065014 Namo Gajah Medan, dapat dilihat rendahnya hasil belajar siswa pada mata pelajaran Matematika

Tabel 1.1 Nilai hasil Ujian Matematika Kelas V SDN 065014

\begin{tabular}{|c|c|c|c|}
\hline \multirow{2}{*}{ KKM Matematika } & \multirow{2}{*}{ Jumlah Siswa } & \multicolumn{2}{|c|}{ Jumlah Siswa } \\
\cline { 3 - 4 } & 20 & 7 siswa (35\%) & Tidak Tuntas \\
\hline 67 & $20(65 \%)$ \\
\hline
\end{tabular}

Dari tabel 1.1 di atas menujukkan bahwa di kelas $\mathrm{v}$ yang berjumlah 20 orang siswa hanya 7 orang siswa yang mencapai nila KKM ( Kriteria Ketuntasan Minimum) dan sebanyak 13 orang siswa belum mencapai KKM (Kriteria Ketuntasan Minimum). Penguasaan Matematika menjadi permasalahan dalam tingkat pendidikan terutama di tingkat Sekolah Dasar (SD). Hal ini terbukti dari Ujian Nasional (UN) yang dilaksanakan oleh pemerintah dapat dilihat bahwa rendahnya persentase kelulusan siswa dalam ujian pelajaran Matematika, dan 
dalam ujian harian (sekolah) yang dilaksanakan pihak sekolah sangat banyak hasil belajar siswa yang tidak mencapai dengan KKM (Kriteria Ketuntasan Minimal) yang telah ditetapkan oleh pihak sekolah, dan hampir rata-rata sekolah megalami masalah dengan hasil belajar pelajaran Matematika. Pada umunya yang menjadi alasan tersebut adalah rendahnya kemampuan siswa dalam materi pelajaran Matematika dan kurang melibatkan siswa dalam kegiatan belajar yang sedang berlangsung.

Rendahnya prestasi belajar Matematika siswa tersebut, tentu banyak faktor yang menyebabkannya, misalnya masalah klasik tentang penerapan metode pembelajaran Matematika yang berpusat pada guru, sementara siswa cendurung pasif. Sistem pengajaran yang demikian ini yang menyebabkan siswa tidak ikut berpartisipasi aktif dalam mengikuti pembelajaran, sehingga dikhawatirkan siswa tidak dapat meningkatkan aktivitas belajar Matematika untuk meningkatkan pengembangan kemampuannya.

Model pembelajaran konvensional ini, biasanya lebih menekankan pada soal latihan pengerjaan soal, model pembelajaran tersebut mendidik siswa bekerja tetapi bukan untuk mengedepankan aspek berpikir atau mandiri. Kegiatan ini terjadi di kelas dengan menggunakan model pembelajaran ceramah atau konvensional ini adalah menyimak penjelasan guru dalam memberikan contoh dan menyelesaikan soal, dan akibatnya jika siswa diberikan soal atau latihan yang berbeda dengan contoh siswa akan merasa kesulitan atau membuat kesalahan dalam mengerjakannya. Hal ini menunjukkan bahwa siswa hanya menghafalkan langkah penyelesainnya tetapi kemampuan pemahaman siswa dikatakan kurang.

Melihat kondisi yang seperti itu, perlu kiranya melakukan pengembangan dan peningkatan mutu saat proses pembelajaran, yakni pembelajaran yang mampu mengoptimalkan interaksi antara siswa dengan guru, siswa dengan siswa. Upaya mengembangkan kemampuan berpikir salah satunya dapat dilakukan dengan membuka pemahaman pada diri siswa tersebut.

Untuk meningkatkan hasil belajar atau mencapai $\mathrm{KKM}($ Kriteria Ketuntasan Minimal) yang telah ditetapkan oleh sekolah, guru harus bisa ikut melibatkan siswa agar tidak hanya berpusat pada guru tetapi juga siswa ikut aktif saat proses belajar mengajar. Guru juga perlu mengganti suasana atau menggunakan model pembelajaran yang sesuai dengan materi yang diajarkan pada saat proses belajar mengajar, sehingga membantu dalam mengembangkan cara berpikir siswa dalam pembelajaran matematika. Agar pembelajaran Matematika dapat dipahami dan meningkatkan hasil belajar serta cara berpikir siswa, guru bisa menggunakan model pembelajaran pada saat proses belajar mengajar. Model pembelajaran dapat diartikan sebagai titik tolak atau sudut pandang kita terhadap proses pembelajaran, yang merajuk pada pandangan tentang terjadinya suatu proses pembelajaran dan pandangan prosess belajar mengajar yang menginsprasi, meningkatkan, terjadinya proses pola berpikir pembelajar, dan salah satunya adalah model pembelajaran kooperatif tipe Student Teams Achieviment Division (STAD).

Menurut Istarani (2011: 19) STAD merupakan salah satu tipe dari kooperatif yang menggunakan kelompok-kelompok kecil dengan jumlah anggota tiap kelompok 4- 5 orang siswa secara heterogen. Oleh karena itu pada proses belajar mengajar mata pelajaran Matematika menggunakan model pembelajaran

Volume: 1 No. 1 Juli 2018

JURNAL ILMIAH AQUINAS TERBIT JULI DAN JANUARI SETIAP TAHUNNYA 
kooperatif tipe STAD karena berkelompok dan dengan berkelompok siswa dapat aktif dan saling bertukar pikiran antara sesama anggota kelompok tentang materi yang sedang dibahas dan dengan saling bertukar pikiran dan bekerja sama antara sesama anggota kelompok tentu akan menambah pemahaman siswa tentang materi yang sedang dibahas dan sesama anggota akan aktif saat proses pembelajaran dan menambah pemahaman siswa tersebut sehingga akan meningkatkan hasil belajar atau mencapai KKM (Kriteria Ketuntasaan Minimal), yang telah ditetapkan.

Berdasarkan uraian tersebut, peneliti tertarik melakukan penelitian dengan judul "MENINGKATKAN HASIL BELAJAR SISWA DENGAN MENGGUNAKAN MODEL PEMBELAJARAN KOOPERATIF TIPE STUDENT TEAMS ACHIEMENT DIVISION (STAD) PADA MATA PELAJARAN MATEMATIKA KELAS V SDN 065014 NAMO GAJAH MEDAN T.P 2017/2018".

\title{
Identifikasi Masalah
}

Berdasarkan latar belakang masalah tersebut, dapat diidentifikasi faktorfaktor penyebab rendahnya hasil belajar siswa pada mata pelajaran Matematika antara lain:

1. Siswa kurang aktif pada saat proses belajar mengajar berlangsung mata pelajaran Matematika

2. Siswa kurang memahami pelajaran yang sedang di ajarakan pada mata pelajaran Matematika

3. Kurangnya pemahaman siswa pada mata pelajaran matematika berdampak pada hasil belajar siswa?

\section{Pembatasan Masalah}

Sesuai dengan identifikasi masalah, masalah dibatasi dan difokuskan padaRendahnya hasil belajar siswa pada mata pelajaran Matematika kelas V materi faktor prima untuk menentukan FPB dan KPK SDN 065014 Namo Gajah Medan T.P 2017/2018.

\section{Perumusan Masalah}

Berdasarkan pembatasan masalah tersebut, dapat dirumuskan masalah penelitian kelas sebagai berikut: Apakah dengan menggunakan tipe Student Teams Achievement Division (STAD) dapat ditingkatkan hasil belajar siswa pada mata pelajaran Matematika kelas V SDN 065014 Namo Gajah Medan T.P $2017 / 2018 ?$

\section{Tujuan Penelitian}

Tujuan penelitian tindakan kelas terdiri atas:

1. Tujuan Umum

Tujuan umun penelitian ini adalah untuk memperbaiki/meningkatkan kualitas proses pembelajaran.

2. Tujuan Khusus

Untuk meningkatkan hasil belajar siswa pada mata pelajaran Matematikakelas V SDN 065014 Namo Gajah Medan T.P 2017/2018.

\section{ManfaatPenelitian}

\author{
1. Guru
}


Penerapan model Pembelajaran Kooperatif tipe Student Team Achievement Division (STAD) dalam pembelajaran Matematika dapat meningkatakan kualitas proses pembelajaran di kelas dan meningktkan keprofesionalan guru sebagai agen pembelajaran dan juga sebagai bahan masukkan bagi guru.

2. Siswa

Hasil penerapan model Pembelajaran Kooperatif tipe Student Team Achievement Division (STAD) pada mata pelajaran Matematika dapat meningkatkan hasil belajar baik pada mata pelajaran matematika atau mata pelajaran lainnya sehingga kemampuan kognitif, psikomotorik, dan afektif siswa semakin meningkat.

3. Sekolah

Sebagai bahan masukkan bagi kepala sekolah dalam meningkatkan keterampilan guru dalam mengajar khususnya menggunakan tipe Student Team Achievement Division (STAD)di SDN 065014 Namo Gajah Medan dan kegiatan proses saling tukar pengalaman.

\section{METODOLOGI PENELITIAN}

\section{Pendekatan Metode Penelitian}

Jenis penelitian yang dilakukan adalah Penelitian Tindakan Kelas menggunakan model Kooperatif tipe Student Teams Achievement Division (STAD). Metode yang digunakan dalam penelitian ini adalah penilitian tindakan kelas. Sanjaya ( 2011: 26) berpendapat "Penelitian tindakan kelas diartikan sebagai proses pengkajian masalah pembelajaran di dalam kelas melalui refleksi diri dalam upaya untuk memecahkan masalah tersebut dengan cara melakukan berbagai tindakan yang terencana dalam situasi nyata serta menganalisis setiap pengaruh dari perlakuan tersebut". Secara etimologis, ada tiga istilah yang berhubungan denga PTK, yaitu penelitian, tindakan, kelas. Penelitian adalah suatu proses pemecahan masalah yang dilakukan secara sistematis, empiris, dan terkontrol. Tindakan dapat diartikan sebagai perlakuan tertentu yang dilakukan oleh peneliti yakni guru. Kelas, kelas menunjukkan pada tempat proses pembelajaran berlangsung. Dari pelaksanaan penelitian yang dilakukan guru ada beberapa hal yang terkait dengan PTK, yakni : pertama, PTK diawali dengang melakukan refleksi diri. Kedua, PTK ditandai dengan adanya tindakan atau perlakuan tertentu yang direncanakan terlebih dahulu untuk memecahkan masalah yang dirasakan. Ketiga, dalam PTK dilaksanakan analisis pengaruh yang ditimbulkan melalui observasi. Tujuan penelitian tindakan kelas ini adalah meningkatkan respons siswa dengan menerapkan model pembelajaran kooperatif tipe stad (student teams achievement division).

Model yang digunakan dalam penelitian ini adalah model Hopkins. Pelaksanaan penelitian ini dilakukan membentuk spiral yang dimulai dari adanya menyusun perencanaan, melaksanakan tindakan, dan seterusnya.

\section{Tempat, Kegiatan dan Waktu Penelitian}

\section{Tempat Penelitian}

Penelitian ini dilakukan di SDN 065014 kelas V NAMO GAJAH MEDAN T.P 2017/2018.

\section{Waktu dan Kegiatan}

Penelitian ini dilaksanakan pada semester ganjil bulan juli 2017/2018.

Volume: 1 No. 1 Juli 2018

JURNAL ILMIAH AQUINAS TERBIT JULI DAN JANUARI SETIAP TAHUNNYA 


\section{Subjek Penelitian}

Dalam penelitian ini yang dijadikan sebagai subjek penelitian adalah seluruh siswa kelas V SDN 065014 NAMO GAJAH MEDAN T.P 2017/2018.

\section{Jenis dan Sumber Data}

\section{Jenis Data}

Data yang digunakan atau yang diperoleh dari penelitian ini ada dua yaitu: data kuantitatif dan data kualitatif.Penilaian kuantitatif ini adalah penilaian yang terdapat dari hasil belajar siswa yang diperoleh melalui tes yang digunakan untuk mengukur kemampuan kognitif siswa. Nilai hasil belajar tersebut diperoleh dari siklus I dan siklus II.Data kualitatif dalam penelitian ini berupa data hasil pengamatan pada saat pembelajaran berlangsung. Data tersebut berupa hasil pengamatan aktivitas siswa yang diperoleh melalui lembar pengamatan

\section{Sumber Data}

Sumber data dalam penelitian ini adalah seluruh siswa kelas V SDN 065014 NAMO GAJAH MEDAN.

\section{Teknik dan Alat Pengumpulan Data}

Dalam mengumpulkan data selama penelitian, peneliti menggunakan berbagai teknik pengumpulan data. Adapun teknik tersebut sebagai berikut:

\section{Observasi}

Menurut Paizaluddin dan Ermalinda (2014: 113) Observasi adalah pengambilan data dalam penelitian di mana peneliti atau pengamat melihat situsi penelitian. Teknik ini digunakan untuk mengamati dari dekat dalam upaya mencari dan mengali data melalui pengamatan secara langsung dan mendalam terhadap subjek dan objek yang diteliti.

\section{Tes}

Menurut Paizaluddin dan Ermalinda (2014: 131) Tes merupakan alat pengukur data yang berharga dalam penelitian. Tes ialah seperangkat rangsangan (stimul) yang diberikan kepada seseorang dengan maksud untuk mendapatkan jawaban-jawaban yang dijadikan penetapan skor angka.

\section{Uji Validitas dan Instrumen}

\section{Uji Validitas Tes}

Uji validitas tes adalah suatu alat yang menunjukkan seberapa jauh suatu instrumen memiliki ketetapan dan kecermatan dalam melakukan fungsi ukurnya. Untuk menguji validitas tes menggunakan SPSS, digunakan rumus korelasi product moment

yaitu sebagai berikut:

(2012: 87)

$$
\mathrm{r} \times \mathrm{xy}=\frac{N \sum X Y-\left(\sum X\right)\left(\sum Y\right)}{\sqrt{\left\{N \sum X^{2}-\left(\sum X\right)^{2}\right\}\left\{N \sum Y^{2}-\left(\sum Y\right)^{2}\right\}}} \quad \ldots \ldots \ldots \ldots . . \quad \text { Arikunto }
$$

keterangan:

rxy : Koefisien korelasi antara variabel $\mathrm{x}$ dan $\mathrm{y}$

$\mathrm{x}$ : Skor tiap item

y : Skor total

$\mathrm{N}$ : Jumlah siswa

\section{Reliabilitas Tes}


Setelah diketahui validitas soal maka dilakukan kembali uji reliabilitas. Reliabilitas soal merupakan ukuran yang menyatakan tingkat keajegan kekonsistenan suatu soal tes. Untuk menafsirkan harga reliabilitas tes harga tersebut dikonsultasikan ke tabel harga kritik korelasi Product Moment pada taraf signifikan $\alpha=0,05$ dan kriterianya $\mathrm{r}_{\text {hitung }}>\mathrm{r}_{\text {tabel }}$ maka tes dikatakan reliabel.

Untuk reliabilitas tes penilaian digunakan K-R 20 sebagai berikut:

$$
\mathbf{r}_{11}=\left(\frac{n}{n-1}\right)\left(\frac{s^{2}-\sum p q}{s^{2}}\right) \quad \ldots \ldots \ldots . . . \text { Arikunto }(2012 ; 115)
$$

keterangan:

r11 : reliabilitas tes secara keseluruhan

$\mathrm{p} \quad$ : proporsi subjek yang menjawab item dengan benar

$\mathrm{q} \quad$ : proporsi subjek yang menjawab item dengan salah $(\mathrm{q}=1-\mathrm{p})$

$\sum \mathrm{pq}$ : jumlah hasil perkalian antara $\mathrm{p}$ dan $\mathrm{q}$

$\mathrm{n} \quad$ : banyaknya item

Menurut Guilford(Jihad dan Haris 2013:181)Koefisien reliabilitas yang dihasilkan data dapat diinterpretasikan seperti dibawah ini:

$$
\begin{array}{ll}
\mathrm{r}_{11}<0,20 & =\text { derajat reliabilitas sangat rendah } \\
0,20<\mathrm{r}_{11} \leq 0,40 & =\text { derajat reliabilitas rendah } \\
0,40<\mathrm{r}_{11} \leq 0,70 & =\text { derajat reliabilitas sedang } \\
0,70<\mathrm{r}_{11} \leq 0,90 & =\text { derajat reliabilitas tinggi } \\
0,90<\mathrm{r}_{11} \leq 1,00 & =\text { derajat reliabilitas sangat tinggi }
\end{array}
$$

\section{Analisis Data}

Untuk data kuantitatif dianalisis dengan menggunakan analisis deskriptif kuantitatif, yaitu suatu metode penelitian yang bersifat menggambarkan kenyataan atau fakta sesuai dengan data yang diperolehdengan tujuan untuk mengetahui hasil belajar yang dicapai siswa juga aktivitas siswa selama pembelajaran serta aktivitas guru dalam pembelajaran.Untuk analisis tingkat keberhasilan atau atau persentase kentutasan belajar siswa setelah proses belajar mengajar berlangsung pada setiap siklusnya, dilakukan dengan cara memberikan evaluasi atau tes akhir siklus berupa soal tes tertulis. Analisis data dengan menggunakan statistik sederhana berikut ini:

\section{Observasi}

$$
\mathrm{Pa}=\frac{\text { Skor Perole han }}{\text { Skor Total }} \times 100 \%
$$

$\mathrm{Pa}=$ Perolehan aspek

Tabel 3.7 Kriteria Tingkat Aspek Penilaian Guru (\%)

\begin{tabular}{|c|c|c|}
\hline \multicolumn{2}{|c|}{ Kriteria Penilaian } & Keterangan \\
\hline 5 & $81 \%-100 \%$ & Baik Sekali \\
\hline 4 & $61 \%-80 \%$ & Baik \\
\hline 3 & $41 \%-60 \%$ & Cukup \\
\hline 2 & $21 \%-40 \%$ & Kurang \\
\hline 1 & $0-20 \%$ & Sangat Kurang \\
\hline
\end{tabular}


Tabel 3.8 Kriteria Tingkat Aspek Penilaian Siswa (\%)

\begin{tabular}{|c|c|c|}
\hline \multicolumn{2}{|c|}{ Kriteria Penilaian } & Keterangan \\
\hline 5 & $90 \%-100 \%$ & Sangat Baik \\
\hline 4 & $70 \%-89 \%$ & Baik \\
\hline 3 & $50 \%-69 \%$ & Cukup \\
\hline 2 & $30 \%-49 \%$ & Kurang \\
\hline 1 & $10 \%-29 \%$ & Sangat Kurang \\
\hline
\end{tabular}

\section{Penilaian Ketuntasan Belajar}

Untuk menghitung persentase ketuntasan belajar,digunakan rumus sebagai berikut:

$\mathrm{P}=\frac{\sum \text { Siswa yang tuntas belajar }}{\sum \text { jumla } h \text { Siswa }} \times 100$

Aqib dkk $(2016 ; 41)$

\section{Tabel 3.8 Kriteria tingkat keberhasilan belajar siswa (\%)}

\begin{tabular}{|c|c|c|}
\hline Tingkat keberhasilan(\%) & Kategori Nilai & Kreteria Nilai \\
\hline$>80 \%$ & A & Sangat tinggi \\
\hline $60-79 \%$ & B & Tinggi \\
\hline $40-59 \%$ & C & Cukup \\
\hline $20-39 \%$ & D & Rendah \\
\hline$<20 \%$ & E & Sangat rendah \\
\hline
\end{tabular}

\section{Penilaian Tes}

Penilaian tugas dan tes diperoleh dengan mencari nilai rata-rata siswa, yang diperoleh dengan rumus:

Keterangan :

$$
X=-\frac{\sum X}{\sum N}
$$

Aqib dkk, $(2016 ; 40)$

$\mathrm{X}=$ Nilai rata-rata

$\Sigma \mathrm{N}=$ jumlah siswa

$\Sigma \mathrm{x}=$ jumlah semua nilai siswa

\section{Uji T}

Uji t ( $t$-test) adalah uji statistik yang digunakan untuk mengetahui nilai kebenaran yang dihipotesiskan oleh peneliti. Hipotesis dalam penelitian ini adalah dengan menggunakan model pembelajaran kooperaif tipe STAD (Student Teams Achievement Division) dapat meningkatkan hasil belajar siswa. Uji t terdiri dari dua jenis yaitu uji berpasangan pada sampel yang sama (paired samples $t$-test) dan uji berpasangan pada sampel yang berbeda (independent samples t-test). Dalam penelitian ini, peneliti menggunakakan uji berpasangan pada sampel yang sama (paired samples t-test). Uji berpasangan pada sampel yang sama (paired samples $t$-test) digunakan untuk melihat perbedaan nilai rata-rata antara prates dan postes. 
Ho ; Tidak ada perbedaan signifikan antara hasil nilai rata- rata prates dan hasil nilai rata-rata postes.

$\mathrm{H} 1$; Ada perbedaan signifikan antara hasil nilai rata-rata dan nilai rata-rata postes.

Siregar (2015:255-264) menjelaskan ada dua tahap pengujian untuk mengambil keputusan penerimaah hipotesis, yaitu: 1) antara $t_{\text {hitung }}$ dan $t_{\text {tabel. }}$. Jika $t_{\text {hitung }}>t_{\text {tabel }}$, tolak $H_{0}$. Itu berarti ada perbedaan signifikan antara hasil nilai ratarata prates dan postes siklus I dan 2. 2) Berdasarkan nilai probabilitas. Jika probabilitas (signifikan) $>0,05$, maka $\mathrm{H}_{0}$ diterima. Untuk melihat pengaruh perbedaan nilai rata-rata prates dan postes, peneliti menggunakan eta square. Eta square adalah besarnya perbedaan antara nilai rata-rata prates dan postes. Untuk mengghitung nilai eta square digunakan rumus sebagai berikut:

Rumus Eta square:

Eta square $=\frac{t^{2}}{t^{2}+(N 1-1)}$

Hasil Eta Square dikreteriakan sebagagai berikut :

Tabel 3.9 Kriteria Nilai Eta Square

\begin{tabular}{|l|l|}
\hline \multicolumn{1}{|c|}{ Eta square } & \multicolumn{1}{c|}{ Kriteria } \\
\hline 0,01 & Dampak kecil \\
\hline 0,06 & Dampak sedang \\
\hline 0,14 & Dampak luas \\
\hline
\end{tabular}

\section{Indikator Kinerja Penelitian}

Penelitian ini dinyatakan berhasil apabila:

1. Nilai rata-rata kelas mengalami peningkatan dari siklus I ke siklus II

2. Tujuh puluh persen $(70 \%)$ siswa mencapai Kriteria Ketuntasan Minimal (KKM) yaitu 70 .

3. Aktivitas guru dan siswa menigkatkan hasil belajar siswa

Prosedur Penelitian

Metode yang digunakan dalam penelitian ini adalah metode penelitian tindakan kelas. Salah satu ciri dalam penelitian tindakan kelas ini adalah adanya tindakan yang dilakukan tiap siklus. Langkah dalam setiap siklus meliputi: perencanaan (planning), pelaksanaan (acting), pengamatan (observing) dan refleksi (reflecting).

\section{HASIL PENELITIAN DAN PEMBAHASAN}

Penelitian yang dilakukan oleh peneliti adalah penelitian tindakan kelas yang dilakukan dalan 2 siklus. Siklus yang dilaksanakan ini terdiri dari siklus 1 dan siklus II, setiap siklus terdiri dari beberapa tahap yaitu: tahap perencanaan, tindakan, obervasi, dan refleksi. Pada siklus II tahap-tahap yang dilakukan merupakan perbaikan dari siklus sebeumnya.

Teknik pengumpulan data pada penelitian ini terdiri dari data tes yang berupa nilai hasil belajar Matematika dan data non tes yang terdiri dari hasil observasi menggunakan lembar aktivitas guru dan siswa. Hasil dari kedua penelitian pada siklus tersebut digunakan untuk mengetahui peningkatan hasil belajar Matematika dengan menggunakan model kooperatif tipe STAD (Student 
Teams Achievement Division) yang diperoleh siswa kelas V SDN 065014 Namo Gajah Medan.

Pada perolehan nilai rata-rata, hasil belajar Matematika kelas V SDN 065014 Namo Gajah Medan pada kondisi awal atau pra siklus dilakukan prates dengan nilai rata-rata yang diperoleh adalah 41,02. Selanjutnya diberikan tindakan berupa penerapan model pembelajaran kooperatif tipe STAD (Student Teams Achievement Divisio) .Pada siklus I rata- rata hasil belajar Matematika kelas V SDN 065014 Namo Gajah Medan meningkat dari 42,75 menjadi 69,5.

Selain itu, tingkat ketuntasan siswa juga mengalami peningkatan dari kondisi awal dimana siswa yang tuntas atau siswa yang memenuhi KKM sebanyak 4 orang atau 16 persen. Pada siklus 1 setelah diberikan tindakan dengan menggunakan model pembelajaran kooperatif tipe STAD (Student Teams Achievement Division) jumlah ketuntasan meningkat menjadi 12 siswa atau 48 persen. Sesuai dengan kriteria keberhasilan ketuntasan siswa yang ditetapkan peneliti sebesar 70 persen maka siklus 1 belum memenuhi kriteria keberhasilan yang diharapakan, maka dilanjutkan pada siklus II dengan tindakan yang sama yaitu penerapan model pembelajaran kooperatif tipe STAD (Student Teams Achievement Division) pada mata pelajaran Matematika.

Pada siklus II ini, rata-rata hasil belajar Matematika yang diperoleh siswa kelas V SDN 065014 Namo Gajah Medan adalah 78,24. Pada siklus II, terjadi peningkatan hasil belajar sebesar 8,74 dan mengalami peningkatan jumlah ketuntasan siswa menjadi 19 siswa atau 76 persen. Dengan demikian model pembelajaran kooperatif tipe STAD (Student Teams Achievement Division) dapat meningkatkan hasil belajar Matematika pada siswa kelas V SDN 065014 Namo Gajah Medan, itu terlihat dari hasil yang diperoleh dari pra tindakan sampai dengan siklus II yang menujukkan adanya peningkatan.

\section{PENUTUP Simpulan}

Berdasarkan hasil penelitian dan pembahasan mengenai upaya meningkatkan hasil belajar siswa dengang menggunakan model pembelajaran kooperatif tipe STAD (Students Teams Achievement Division) mata pelajaran matematika di kelas V SDN 065014 Namo Gajah diperoleh data sebagai berikut:

1. Keterampilan guru dalam pembelajaran Matematika materi faktor prima untuk menentukan FPB dan KPK melalui model pembelajaran kooperatif tipe STAD (Students Teams Achievement Division) mengalami peningkatan tiap siklusnya. Hal ini dapat dilihat berdasarkan rata-rata persentase skor aktivitas guru pada siklus 1 sebesar 70 persen dengan kriteria baik. Pada siklus II meningkat dengan perolehan 78 persen dengan kriteria baik.

2. Aktivitas siswa dalam pembelajaran matematika materi faktor prima untuk menentukan FPB dan KPK melalui model pembelajaran kooperatif tipe STAD (Students Teams Achievement Division) mengalami peningkatan tiap siklusnya. Hal ini dapat dilihat berdasarkan skor aktivitas siswa pada siklus 1 sebesar 71 persen dengan kriteria tinggi. Pada siklus II meningkat menjadi 76 persen dengan kriteria kriteria baik.

3. Hasil belajar dalam pembelajaran matematika materi faktor prima untuk menentukan FPB dan KPK mengalami peningkatan. Hal ini dapat dilihat 
dari ketuntasaan belajar secara klasikal dan nilai rata- rata siswa. Pada prates ketuntasan secara klasikal sebesar 16 persen dengan rata-rata 41,04. Siklus 1 ketuntasan klasikal 48 persen dengan rata-rata 69,52 dan siklus II ketuntasan klasikan mencapai 76 persen dengan rata-rata 78,24.

\section{Implikasi}

Penelitian ini memberikan suatu gambaran yang jelas bahwa keberhasilan proses pembelajaran tergantung dari beberapa faktor. Faktor - faktor tersebut bisa berasal dari pihak guru, siswa, dan model pembelajaran yang dilakukan guru. Berdasarkan hasil penelitian pada pembelajaran matematika dengan menggunkan model pembelajaran kooperatif tipe STAD (Students Teams Achievement Division) adanya peningkatan hasil belajar siswa. Oleh karena itu implikasi yang diperoleh dari penelitian ini, yaitu:

1. Bagi siswa, pelaksanaan model pembelajaran kooperatif tipe STAD (Students Teams Achievement Division) memberikan perubahan yang baik dan mampu meningkatkan hasil belajar siswa.

2. Bagi guru, dengan menerapkan model pembelajaran kooperatif tipe STAD (Students Teams Achievement Division) dapat dijadikan sebagai bahan pertimbangan guru dalam menerapkan model pembelajaran yang inovatif baik dalam pelajaran matematika atau pelajaran lainnya.

3. Bagi sekolah, dengan penerapan model pembelajaran yang tepat dapat menciptakan pembelajaran di sekolah menjadi lebih efisien dan aktif sehingga terjadi peningkatan kualitas dan mutu pendidikan.

4. Bagi peneliti, penelitian dengan menerapkan model pembelajaran kooperatif tipe STAD ( Students Teams Achievement Division) ini dapat dijadikan sebagai bahan referensi untuk diterapkan ketika menjadi seorang guru.

\section{Keterbatasan Penelitian}

Dalam penelitian ini terdapat keterbatasan yang diharapkan akan memberikan kesempatan bagi peneliti yang lainnya untuk melakukan penelitian sejenis yang akan berguna bagi perluasan wawasan keilmuan. Adapun keterbatasan penelitian ini adalah:

1. Subjek dan objek penelitian hanya berasal dari satu sekolah yaitu siswa kelas V SDN 065014 Namo Gajah, sehingga hasil penelitian ini belum tentu sesuia dengan sekolah lain.

2. Penelitian ini hanya terbatas pada penerapan model pembelajaran kooperatif tipe STAD (Students Teams Achievement Division) untuk meningkatkan hasil belajar Matematika tentang faktor prima untuk menentukan FPB dan KPK.

\section{Saran}

Berdasarkan hasil penelitian yang telah dilaksanakan, model pembelajaran kooperatif tipe STAD (Students Teams Achievement Division) dapat meningkatkan hasil belajar siswa kelas V SDN 065014 Namo Gajah Medan. Saran yang dapat diberikan adalah sebagai berikut:

1. Bagi guru, guru perlu meningkatkan keterampilan dalam melaksanakan pembelajaran dengan menerapkan model pembelajaran inovatif dan memanfaatkan media yang sesuai dengan karakteristik siswa, sehingga dapat meningkatkan profesionalisme guru dan dapat meningkatkan keaktifan siswa dalam pembelejaran. 
2. Bagi sekolah, sebagai bahan masukan guru kelas untuk menerapkan pembelajaran yang inovatif dan memanfaatkan media pembelajaran agar kegiatan pembelajaran lebih meyenangkan sehingga dapat meningkatkan kualitas pembelajaran.

3. Bagi peneliti lainnya, diharapakan untuk lebih banyak lagi mencari informasi mengenai model pembelajaran agar dapat menggunakan model pembelajaran yang tepat sehingga tujuan pembelajaran dapat tercapai.

\section{DAFTAR PUSTAKA}

Aqib, Zainal, dkk. 2001. Penelitian Tindakan Kelas untuk SD, SLB, dan TK. Bandung: CV Yrama Widya

Arikunto, Suharsimi. 2012. Dasar-Dasar Evaluasi Pendidikan. Jakarta : Bumi Aksara

Asep Jihad dan Abdul Haris. 2013. Evaluasi Pembelajaran.Yogyakarta: Multi Presindo.

Dimyati dan Mudjiono.2012. Belajar dan Pembelajaran. Jakarta: Rineka Cipta. Hamdayana, Jumanta. 2014. Model dan Metode Pembelajaran Kreatif dan Berkarakter. Bogor: Ghalia Indonesia.

Istarani. 2011. 58 Model Pembelajaran Inovatif. Medan: Media Persada.

Muhammedi, Elfidayati. 2017. Psikologi Belajar. Medan : Larispa Indonesia

Nurhayati, Neli.2010.Penerapan Model Pembelajaran Kooperatif Tipe STAD Berbasis Reaslistik Untuk Meningkatkan Hasil Belajar Matematika Pada Siswa Kelas IV SDN Kebaturan Bawang Batang.Universitas

Skripsi pdf.Universitas Negeri Semarang.

Pazaluddin dan Ermalinda.2012 . Penelitian Tindakan Kelas. Bandung : Alfabeta Pujiati. 2008. Peningkatan Motivasi dan Peningkatan Belajar Matematika Melalui Pembelajaran Kooperatif Tipe STAD.

Rusman.2013. Belajar Dan Pembelajaran Berbasis Komputer. Bandung : Alfabeta

Sanjaya. Wina.2011. Penelitian Tindakan Kelas.Jakarta: Kencana Prenada Media

Surianta. 2009. Penerapan Model Pembelajaran Kooperatif STADdengan Media VCD untuk Meningkatkan Prestasi Belajar Matematika.

Sumiati dan Asra.2010. Metode Pembelajaran. Bandung :CV Wacana Prima. Suprijono, Agus. 2012. Cooperative Learning. Yogyakarta : Pustaka Pelajar.

Susanto, Ahmad. 2013. Teori belajar dan Pembelajaran. Yogyakarta : Multi Presindo

Tampubolon, Saur. 2014. Penelitian Tindakan Kelas. Jakarta: Erlangga. 